\title{
A Study on the Wind Energy Potential in the Romanian Coastal Environment
}

\author{
Florin Onea *(D) and Liliana Rusu \\ Department of Mechanical Engineering, Faculty of Engineering, Dunarea de Jos University of Galati, \\ 47 Domneasca Street, 800008 Galati, Romania; liliana.rusu@ugal.ro \\ * Correspondence: florin.onea@ugal.ro; Tel.: +40-743-932-978
}

Received: 19 March 2019; Accepted: 9 May 2019; Published: 13 May 2019

\begin{abstract}
At the European level, offshore wind projects are already considered a competitive market. Nevertheless, this is not yet the case of the enclosed sea basins, such as the Black Sea, where no offshore wind farm is operating at this moment. From this perspective, the objective of the present work is to identify the most suitable sites where a wind project can be developed in the Romanian coastal areas. Various parameters, such as wind speed, water depth, distance to shore, and turbine performance, are considered. A picture of the local wind characteristics is first provided considering 20 years of reanalysis data, which cover the time interval from January 1998 to December 2017. The results indicated that the best sites to implement a wind project are located in the northern sector of the Black Sea, close to the Danube Delta. It was also noticed an important variation of the wind speed between onshore and $20 \mathrm{~km}$ offshore, for which an increase of about $55 \%$ was estimated.
\end{abstract}

Keywords: Romanian coastal areas; renewable energy; offshore wind; turbines; reanalysis data

\section{Introduction}

The energy future represents a permanent point of debate, especially in the EU (European Union) countries, which constantly establish objectives and performance criteria. The current objectives and performance criteria are focused on the interval 2020-2030. In general, the discussions are carried out around the same topics that involve global warming, energy security strategy, or the dependency on fossil fuel energy consumption [1]. One way to support these measures is to identify and use new renewable sources of energy, such as the ones from the marine environment, where it is possible to develop large-scale projects.

One of the most affordable sources of energy seems to be offshore wind, where new technical solutions have already been proposed, such as the emerging floating platforms able to be deployed in deep water areas [2-4]. The investments and the technological innovations accounted by this sector are also visible in the price of the energy produced. Thus, it is estimated that, for the first time, the offshore wind power is now cheaper than the nuclear power [5]. At the end of the year 2017, the European market was defined by a total capacity of $15.8 \mathrm{GW}$, from which almost $3.1 \mathrm{GW}$ were added only in 2017 (including the first floating wind project). Furthermore, 11 other offshore projects are under construction. This will increase the existing market by $2.9 \mathrm{GW}$, and it is expected that the total installed capacity will be close to $25 \mathrm{GW}$ by 2020 . On average, the existing wind farms are deployed in water depth around $27.5 \mathrm{~m}$, while the distance from the shore is about $40 \mathrm{~km}$. Almost $98 \%$ of all capacity can be found in the UK, Germany, Denmark, Netherlands, and Belgium [6].

However, at this moment, it seems more economically viable to invest in onshore wind projects, although the offshore projects generate more electricity. If we look at the onshore projects from Germany (for the year 2018), it is estimated that it is necessary to invest between $1500 \mathrm{EUR} / \mathrm{kW}$ and $2000 \mathrm{EUR} / \mathrm{kW}$ in order to obtain a levelized cost of electricity (LCOE) between 4 and $8.2 €$ cents $/ \mathrm{kWh}$. 
On the other hand, in the case of the offshore projects, we may expect LCOE values between 7.5 and $13.8 €$ cents $/ \mathrm{kWh}$, which are influenced by the higher investment and installation costs that may reach a maximum value of $4700 \mathrm{EUR} / \mathrm{kW}$. Nevertheless, if we look on medium- to long-term predictions (year 2035), it is expected that the offshore LCOE values will significantly decrease until a minimum value of $5.67 €$ cents $/ \mathrm{kWh}$, which indicates that this sector is expected to have similar or better performances than the onshore wind projects [7].

There is a definite interest to develop wind projects in different coastal areas that are defined by important wind energy resources [8-10]. If we discuss Europe, a special attention needs to be given to the enclosed seas. Thus, in a study by Onea et al. [11], a general analysis of the wind resources from the Mediterranean Sea was carried out, including the evaluation of the performances of a wind turbine defined by a $3 \mathrm{MW}$-rated power. According to these results, the best sites to develop a wind project are located in the west side of the basin (the Levantine Basin), the north (Adriatic Sea), and close to the French coasts. The wind resources from the Mediterranean region were also evaluated in Balog et al. [12], where a hotspot located in the vicinity of the French area was identified. In a study by Satir et al. [13], several wind farm configurations that may operate in the Aegean Sea were proposed. According to these results, to develop such projects will be profitable, and even better results are expected than in the case of Germany, France, or Belgium.

The Black Sea coastal environment seems to represent a point of attraction for the onshore wind farms, taking into account the large number of projects developed in this area. For example, in the case of Romania, almost 78\% of the existing wind turbines are concentrated in the Dobrogea Plateau, which is located near the Black Sea. These values also include one of the largest onshore wind farms from Europe, namely, the 600 MW Fantanele-Cogealac project [14]. A total installed capacity of $946 \mathrm{MW}$ was reported for the coastal regions of Turkey (at the end of 2013), while almost $5 \%$ of this capacity is located close to the Black Sea coast [15]. A possible explanation or this small percentage is related to the fact that almost $14.3 \%$ of the total wind energy is linked to the Black Sea, compared to $43.9 \%$ estimated for the Marmara Sea [16].

At this point, it must also be highlighted that most of the existing studies focused on the Black Sea are describing the wind conditions from a meteorological or a climatological point of view [17-20]. An offshore wind atlas was designed for this area based on 37 years of reanalysis data processed for the height of $50 \mathrm{~m}$ above the sea level [21]. Although a complete image of the wind power is provided for this area, it is important to mention that most of the offshore wind turbines operate at a hub height of minimum $80 \mathrm{~m}$ [22]. The performances of some state-of-the-art wind turbines were recently discussed for several reference sites distributed along the entire Black Sea coastline [23-25]. Thus, the rated capacity of the selected wind turbines varies from $3 \mathrm{MW}$ to $9.5 \mathrm{MW}$, covering the existing operational systems and the new generation turbines expected to be implemented in the near future. During the winter time (December-January-February), the best performances are encountered, with more promising results being noticed close to the Crimea Peninsula and in the north-west region. Another important finding is that, compared to some other European sites where wind projects operate (or are planned to be implemented), the best wind resources from the Black Sea do not indicate higher values. Some other studies suggest that significant wind resources can be found in the Azov Sea [26]. A study by Rusu [27] presents a complete description of the wind resources in the western part of this basin, based on the analysis of the data corresponding to the 30-year time interval from 1987 to 2016, by considering wind fields (at $80 \mathrm{~m}$ height) from the US National Centers for Environmental Prediction. For the sites located in this area, close to the shore, the average wind power is estimated to be between $107 \mathrm{~W} / \mathrm{m}^{2}$ and $555 \mathrm{~W} / \mathrm{m}^{2}$, with more important resources being noticed close to the Danube Delta and Odessa region. However, in that work, the expected performances of some wind turbines were not taken into account.

Finally, by summarizing the existing literature review focused on the Black Sea coastal areas (either nearshore or offshore), we may notice that the studies focused on the electricity production expected from the wind resources are quite limited, which seems to represent a gap. Therefore, the aim 
of the present work is to identify the performances of some offshore wind turbines that may operate close to the Romanian coastal areas. From this perspective, the following research questions will guide the present work: (a) What are the differences between the onshore and the offshore wind resources; (b) how the wind varies from north to south; (c) what is the best site to develop a wind project; (d) what type of European offshore wind project will be more suitable for the Romanian coastal areas.

\section{Materials and Methods}

\subsection{Target Area}

The Black Sea wind climate is influenced by the action of the continental, marine tropical, and polar air masses. The impact of the polar air masses (coming from north and northeast) is more visible during the winter season, when low temperatures and frequent storms may occur in this region. Also, it is estimated that the joint evolution of the North Atlantic Oscillation and El Nino-Southern Oscillation systems influence the storm occurrences over the Mediterranean area, and one of the effects is the increase of the wind conditions in the Black Sea during the winter time. In general, it is considered that the western part of the Black Sea is defined by more important wind resources, with average wind speed values of $8 \mathrm{~m} / \mathrm{s}$ during the winter [28].

The Romanian Exclusive Economic Zone (EEZ) is defined by an area of 22,486 $\mathrm{km}^{2}$ and by a territorial sea of $4084 \mathrm{~km}^{2}$, which is associated to $5.3 \%$ of the entire Black Sea coastline. It is estimated that almost $4.5 \%$ of the Romanian population lives in this coastal region, which can be divided in two sectors: (a) The northern part-the Danube Delta Biosphere Reserve and the sector between Musura Bay and Cape Midia (162 km); (b) the southern part between Cape Midia and Vama Veche, mainly known for its touristic and economical activities [29]. More details about the target area considered are presented in Figure 1, where several reference sites are also defined for assessment.

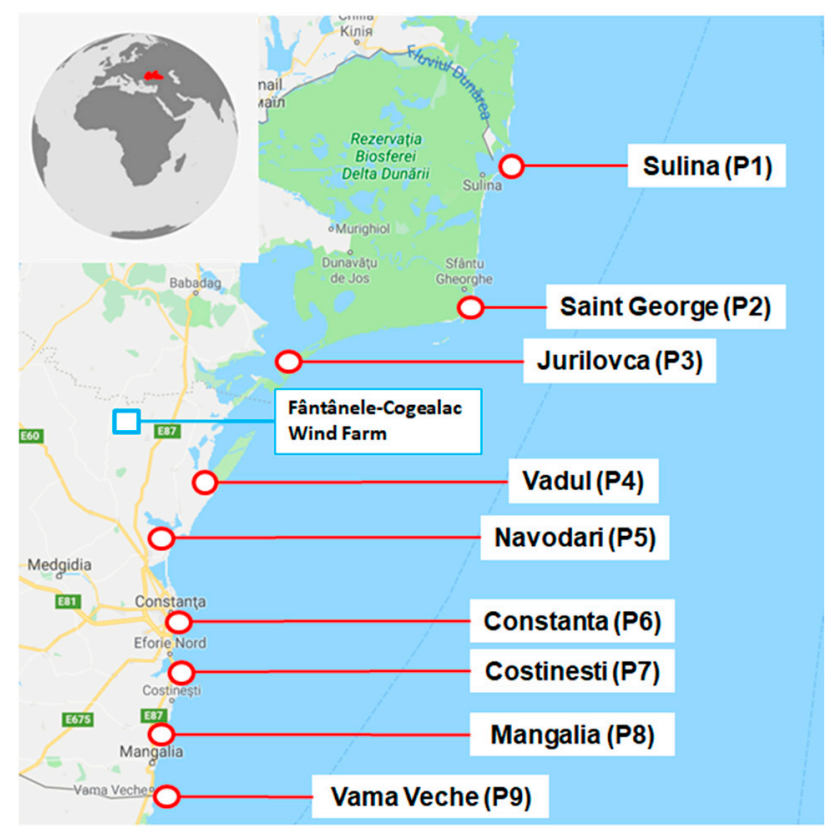

Figure 1. The Romanian coastal area and the onshore reference sites considered for assessment (map from Google Earth, 2019).

The reference sites considered in this work are located onshore (along the coastline), being distributed along the entire Romanian coastal area. In the northern sector, the selected sites were Sulina, Saint George, Jurilovca, and Vadul, and also included the Fântânele-Cogealac Wind Farm, located approximately $17 \mathrm{~km}$ from the Black Sea shoreline. The southern sector includes the remaining sites: Navodari, Constanta, Costinesti, Mangalia, and Vama Veche. In order to assess the variation 
of the wind resources from the shore to offshore, several distances from the coast were considered for investigation $(20 \mathrm{~km}, 40 \mathrm{~km}, 60 \mathrm{~km}, 80 \mathrm{~km})$ for each onshore site (excluding Fântânele-Cogealac site). Figure 2 illustrates the associated water depths of these sites according to the data presented on the Geoplaner website (https://www.geoplaner.com/), for which an average value of $41.8 \mathrm{~m}$ is noticed. The following depth intervals are noticed: $20 \mathrm{~km}$ offshore- $30.6 \mathrm{~m}$ and $51 \mathrm{~m} ; 40 \mathrm{~km}-25.5 \mathrm{~m}$ and $58.5 \mathrm{~m}$; $60 \mathrm{~km}-21 \mathrm{~m}$ and $77.2 \mathrm{~m} ; 80 \mathrm{~km}-55.9 \mathrm{~m}$ and $88.9 \mathrm{~m}$. Compared to the year 2018, the European offshore wind industry was defined by an average water depth of $27.1 \mathrm{~m}$ and a distance from the shore of $33 \mathrm{~km}$, which decreased from $41 \mathrm{~km}$, as it was in 2017. It must be noticed that the farthest projects from the shore $(103 \mathrm{~km}$ ) are the Hornsea One (UK) and EnBW Hohe See (Germany), while the project Kincardine Pilot (Scotland-floating project) is associated to a $77 \mathrm{~m}$ water depth and a $15 \mathrm{~km}$ distance to the shore [6]. Considering this, it seems that a floating project will be more suitable for the Romanian environment, taking into account that even the sites located at $20 \mathrm{~km}$ or $40 \mathrm{~km}$ offshore are defined by relatively high water depths.

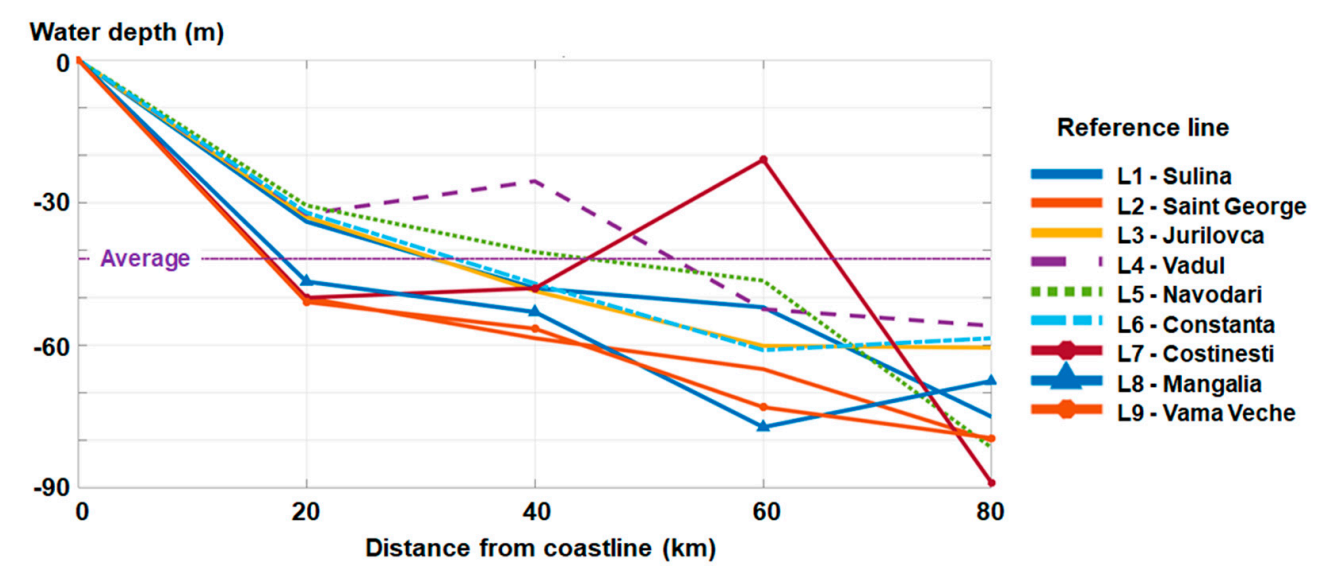

Figure 2. Variation of the water depth for each site considering various distances from the shore $(0 \mathrm{~km}$, $20 \mathrm{~km}, 40 \mathrm{~km}, 60 \mathrm{~km}$, and $80 \mathrm{~km}$ ).

\subsection{Wind Dataset}

The present work involves the wind fields provided by the ERA-Interim database, which is a project maintained by the European Centre for Medium-Range Weather Forecasts (ECMWF). This reanalysis project covers various meteorological parameters reported on a global scale from 1979 to the present [30,31]. Nevertheless, in this work, only the 20-year time interval from January 1998 to December 2017 was processed for the Romanian sector. The wind speed is evaluated at $10 \mathrm{~m}$ height (above the sea or the ground level), being defined by a spatial resolution of $0.125^{\circ} \times 0.125^{\circ}$ and a temporal resolution of $6 \mathrm{~h}$ (four values per day, 00-06-12-18 UTC, respectively). At this point, it is important to mention that from the comparison carried out with some in-situ wind measurements performed in the northwestern part of this basin (including Romania), it seems that the local wind speeds lower than $7 \mathrm{~m} / \mathrm{s}$ are overestimated by the ERA-Interim dataset, while those higher than this threshold are underestimated [32]. To assess the wind conditions at a $10 \mathrm{~m}$ height (U10) might be suitable from a meteorological point of view [33], but for a renewable project, it is more appropriate to assess these resources at a height of $80 \mathrm{~m}[22,34]$, since this height represents the minimum level at which an offshore wind generator usually operates. In order to make this adjustment, the following Equation can be considered [35]:

$$
U 80=U 10 \cdot \ln \left(\frac{z 80}{z_{0}}\right) / \ln \left(\frac{z 10}{z_{0}}\right)
$$

where $U 80$ is the wind speed at $80 \mathrm{~m}$ height of (z80); $U 10$ represents the initial wind conditions at $10 \mathrm{~m}$ (z10), while $z 0$-is the roughness factor (calm sea surface $-0.0002 \mathrm{~m}$; open agricultural area $-0.03 \mathrm{~m}$ ) [36]. 
Besides the wind speed, another way to assess the wind energy potential of a particular site is by considering the wind power density $\left(W P D\right.$-in $\left.\mathrm{W} / \mathrm{m}^{2}\right)$. This can be expressed as [35]:

$$
W P D=\frac{1}{2} \rho_{\text {air }} U 80^{3}
$$

where, $\rho_{\text {air }}$-is air density and U80-wind speed at $80 \mathrm{~m}$ height.

\subsection{Wind Turbines}

For the present work, three different wind turbines will be considered for the wind energy assessment, as shown in Table 1 and Figure 3. The system GE Energy 2.5xl is designed to operate only on land. Therefore, this generator will be used to assess the performances of the onshore sites. The SWT-2.3-93 and Areva M5000-116 turbines are frequently used in the existing offshore wind farms, and as a consequence, their performances will be considered for the marine sites. Some turbines are defined by a broader range of hub heights at which they can operate, and in order to simplify the present work, the highest hub height is considered (the underlined values). The Areva M5000-116 turbine has the highest rated power ( $5 \mathrm{MW}$ ), but it is designed to operate at a hub height of $90 \mathrm{~m}$, compared to the other two turbines that do not exceed 2.5 MW, but are associated to a hub height of $100 \mathrm{~m}$. Nevertheless, the Areva M5000-116 wind turbine is defined by the lowest rated speed value, which, when combined with the rated power, will definitely lead to a higher power production.

Table 1. Main specifications of the wind turbines considered for evaluation.

\begin{tabular}{ccccccc}
\hline Turbine & $\begin{array}{c}\text { Rated } \\
\text { Power } \\
\text { (MW) }\end{array}$ & $\begin{array}{c}\text { Cut-in } \\
\text { Speed } \\
\mathbf{( m / s )}\end{array}$ & $\begin{array}{c}\text { Rated } \\
\text { Speed } \\
\mathbf{( m / s )}\end{array}$ & $\begin{array}{c}\text { Cut-out } \\
\text { Speed } \\
\mathbf{( m / s )}\end{array}$ & $\begin{array}{c}\text { Hub Height } \\
\mathbf{( m )}\end{array}$ & Reference \\
\hline GE Energy 2.5xl & 2.5 & 3.5 & 13.5 & 25 & $75-\underline{100}$ & {$[37]$} \\
SWT-2.3-93 & 2.3 & 4 & 13.5 & 25 & $80-\overline{101}$ & {$[38,39]$} \\
Areva M5000-116 & 5 & 4 & 12.5 & 25 & 90 & {$[40]$} \\
\hline
\end{tabular}

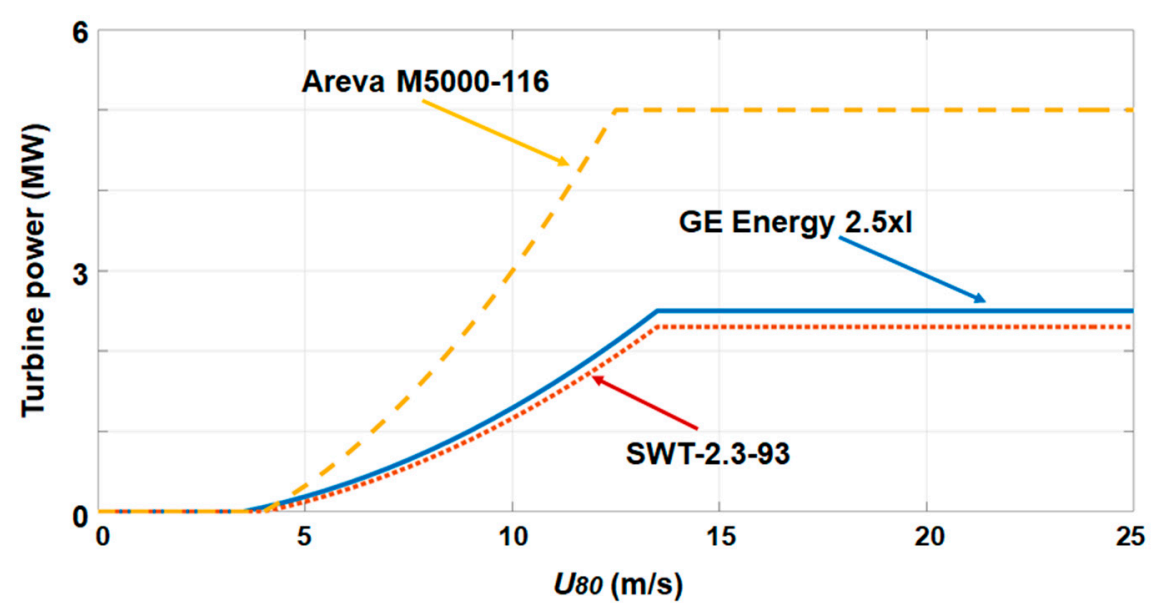

Figure 3. Power curves of the GE Energy 2.5xl, SWT-2.3-93 and Areva M5000-116 wind turbines considered for evaluation.

The Annual Electricity Production $(A E P)$ of a particular wind turbine can be estimated as [41]:

$$
A E P=T \times \int_{\text {cut-in }}^{\text {cut-out }} f(u) P(u) d u
$$


where $A E P$ is expressed in $\mathrm{MWh}, T$-represents the average number of hours per year $(8760 \mathrm{~h} /$ year), $f(u)$-is the Weibull probability density function, $P(u)$ 一the power curve of a turbine, cut-in/cut-out—the turbine characteristics.

The Weibull probability density function, can be expressed as follows [42]:

$$
f(u)=\left(\frac{k}{c}\right)\left(\frac{u}{c}\right)^{k-1} \exp \left[-\left(\frac{u}{c}\right)^{k}\right]
$$

where $u$-is the wind speed; $k$ - the shape parameter; $c$-is the scale parameter (in $\mathrm{m} / \mathrm{s}$ ).

One way to estimate the reliability of a particular system (wind turbine or Wave Energy Converter) is to evaluate the capacity factor $\left(C_{f}\right)$, which is defined as [24]:

$$
C_{f}=\frac{P_{\text {turbine }}}{P_{\text {rated }}} \cdot 100
$$

where $P_{\text {turbine }}$-represents the electric power expected to be generated by each system and $P_{\text {rated }}$-the rated power of each generator.

\section{Results}

\subsection{Analysis of the Wind Resources}

Figure 4 provides a first analysis of the offshore wind conditions in the Romanian coastal environment. From the analysis of the parameter $U 80$ (Figure 4a), we may notice that, from the onshore sites, the best wind resources correspond to Sulina $(6.6 \mathrm{~m} / \mathrm{s})$ and Vama Veche $(6.4 \mathrm{~m} / \mathrm{s})$, which are closely followed by Jurilovca with $6.3 \mathrm{~m} / \mathrm{s}$. As we go to the offshore areas, we may notice smaller variations between the sites considered, with the values encountered being in the ranges: (6.4-6.9) $\mathrm{m} / \mathrm{s}$ (20 km offshore); (6.6-7.3) m/s (40 km); (6.8-7.2) m/s $(60 \mathrm{~km})$ and $(7-7.3) \mathrm{m} / \mathrm{s}(80 \mathrm{~km})$.

\section{$U 80(\mathrm{~m} / \mathrm{s})$}

(a)

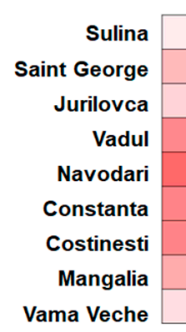

(c)

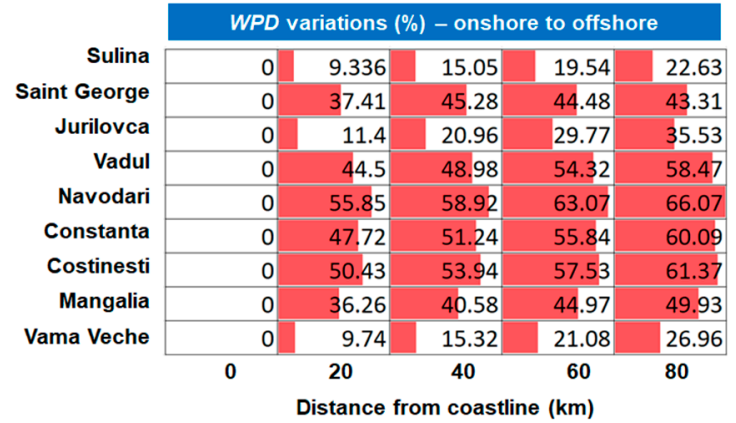

(b)

\begin{tabular}{|r|r|r|r|r|}
\hline 308.8 & 340.6 & 363.5 & 383.8 & 399.1 \\
\hline 227.9 & 364.1 & 416.5 & 410.5 & 402 \\
\hline 269.6 & 304.3 & 341.1 & 383.9 & 418.2 \\
\hline 164.5 & 296.4 & 322.4 & 360.1 & 396.1 \\
\hline 129.1 & 292.4 & 314.3 & 349.6 & 380.5 \\
\hline 159.4 & 304.9 & 326.9 & 361 & 399.4 \\
\hline 160.9 & 324.6 & 349.3 & 378.9 & 416.5 \\
\hline 208.8 & 327.6 & 351.4 & 379.4 & 417 \\
\hline 294.7 & 326.5 & 348 & 373.4 & 403.5 \\
\hline
\end{tabular}

(d)

\begin{tabular}{|r|r|r|r|r|}
\hline \multicolumn{5}{|c|}{ WPD variations $(\%)-$ north to south } \\
\hline 0.00 & -6.90 & -14.58 & -6.96 & -4.79 \\
\hline-35.50 & 0.00 & 0.00 & 0.00 & -4.03 \\
\hline-14.54 & -19.65 & -22.10 & -6.93 & 0.00 \\
\hline-87.72 & -22.84 & -29.19 & -14.00 & -5.58 \\
\hline-139.20 & -24.52 & -32.52 & -17.42 & -9.91 \\
\hline-93.73 & -19.42 & -27.41 & -13.71 & -4.71 \\
\hline-91.92 & -12.17 & -19.24 & -8.34 & -0.41 \\
\hline-47.89 & -11.14 & -18.53 & -8.20 & -0.29 \\
\hline-4.79 & -11.52 & -19.68 & -9.94 & -3.64 \\
\hline $\mathbf{0}$ & $\mathbf{2 0}$ & $\mathbf{4 0}$ & $\mathbf{6 0}$ & $\mathbf{8 0}$ \\
\hline & Distance from coastline (km) \\
\end{tabular}

Figure 4. The spatial distribution of the wind parameters, considering the ERA-Interim data for the time interval from January 1998 to December 2017. The results are indicated for: (a) U80 parameter-average values; (b) WPD parameter-average values; (c) WPD variations-onshore to offshore; (d) WPD variations-north to south, considering the maximum value (per each column) as a reference.

Nevertheless, we can notice that the site Saint George $(40 \mathrm{~km})$ seems to represent the best location for a wind project, taking into account that it indicates a similar value of the parameter U80 with the 
one indicated by the Jurilovca site $(80 \mathrm{~km})$. A similar analysis is illustrated in Figure $4 \mathrm{~b}$, where this time, the WPD parameter is considered. More important differences are noticed as we go from onshore to offshore $(20 \mathrm{~km})$, especially in the case of the sites located in the central area. In Figure $4 \mathrm{c}$, the variation of the parameter WPD relative to the onshore sites is presented, and the estimation is made from the onshore sites (associated with zero values) to offshore. WPD was considered for this analysis since it illustrates clearer the wind power variations.

For the sites Sulina and Vama Veche, the values of the WPD variation oscillate in the ranges (9.33-22.63)\% and (9.74-26.96)\%, with these values being significantly smaller compared to other sites. A maximum value of $66.07 \%$ is expected for the Navodari site. This value gradually increases from $55.85 \%$, as it is reported near the shore $(20 \mathrm{~km})$. The sites Constanta and Costinesti also show maximum variations that exceed $60 \%$ (at $80 \mathrm{~km}$ ), compared to $49.93 \%$ corresponding to Mangalia. In the case of Saint George, the sites located between $40 \mathrm{~km}$ and $80 \mathrm{~km}$ offshore constantly indicate values around $44 \%$.

The above observation suggests that in this area, an offshore farm is not more efficient than one closer to shore. Going from north to south (Figure 4d), the WPD variations were associated to the maximum values indicated per each depth column $(0 \mathrm{~km}, 20 \mathrm{~km}$, etc.). The onshore sites present more important values, with an expected decrease of the wind resources of $139.2 \%$ in the case of Navodari site, while a minimum of $4.79 \%$ is related to the Vama Veche site. Considering the Saint George site as a reference, from the offshore sites located between $20 \mathrm{~km}$ and $60 \mathrm{~km}$, it can be expected a decrease of the wind resources in the range (6.9-32.52)\%. For the sites located at $80 \mathrm{~km}$, the WPD variations do not exceed $10 \%$, with noticed minimum values of $0.29 \%$ and $0.41 \%$ compared to Jurilovca site, while a $4.03 \%$ and $5.58 \%$ may be expected in the other sites from this sector.

The Weibull probability distribution is presented in Figure 5 for some reference sites, from which it can be noticed that Navodari presents a particular distribution defined by $\lambda=5.51$ and $\mathrm{k}=2.17$. The rest of the sites have wind conditions in the range $(15-20) \mathrm{m} / \mathrm{s}$ that will significantly increase the power output of an offshore wind turbine. Another important aspect is that none of the sites indicate wind conditions higher than $25 \mathrm{~m} / \mathrm{s}$, which represents the cut-out threshold for most of the existing offshore wind generators.

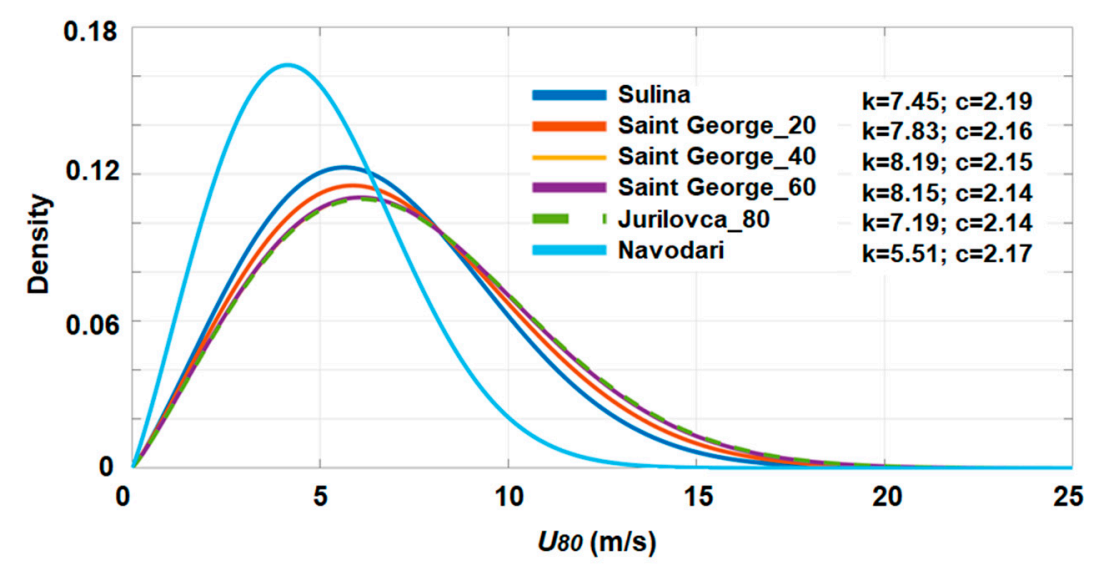

Figure 5. Weibull PDF distributions indicated for some reference sites, considering ERA-Interim data reported for the time interval from January 1998 to December 2017.

\subsection{Assessment of the Wind Turbine Performances}

Figure 6 illustrates the downtime values computed for the wind turbines, considering only those values located below the cut-in limit of each system. For the onshore sites, only the GE Energy 2.5xl turbine was considered (Figure 6a), while for the offshore locations (Figure 6b,c), the SWT-2.3-93 and Areva M5000-116 generators were evaluated. Regarding the onshore sites, the highest inactivity period 
is noticed close to Navodari $(30.16 \%)$, being followed by Constanta $(25.1 \%)$ and Costinesti/Vadul with $24.3 \%$.

\begin{tabular}{|c|c|c|c|c|c|}
\hline & \multirow[b]{2}{*}{$5 x I$ (onshore) } & Downtime (\%) & \multirow{2}{*}{\multicolumn{2}{|c|}{ SWT-2.3-93 (offshore) }} & \\
\hline a) GE Energy 2 & & b) & & & \\
\hline Sulina & 16.29 & 20.57 & 20.18 & 19.63 & 20.57 \\
\hline Saint George & 19.55 & 20.01 & 18.52 & 18.95 & 19.01 \\
\hline Jurilovca & 17.59 & 21.72 & 20.62 & 19.5 & 18.58 \\
\hline Vadul & 24.31 & 22.18 & 21.38 & 20.45 & 19.32 \\
\hline Navodari & 30.16 & 22.6 & 21.83 & 20.79 & 19.96 \\
\hline Constanta & 25.1 & 22.06 & 21.47 & 20.46 & 19.35 \\
\hline Costinesti & 24.3 & 21.3 & 20.72 & 19.8 & 18.73 \\
\hline Mangalia & 20.73 & 21.38 & 20.69 & 19.79 & 18.77 \\
\hline \multirow[t]{13}{*}{ Vama Veche } & 17.17 & 21.52 & 20.96 & 20.22 & 19.3 \\
\hline & & c) & \multicolumn{3}{|c|}{ Areva M5000-116 (offshore) } \\
\hline & Sulina & 20.9 & 20.49 & 19.92 & 20.9 \\
\hline & Saint George & 20.3 & 18.93 & 19.25 & 19.32 \\
\hline & Jurilovca & 22.09 & 20.97 & 19.88 & 18.86 \\
\hline & Vadul & 22.56 & 21.78 & 20.76 & 19.62 \\
\hline & Navodari & 22.96 & 22.19 & 21.13 & 20.3 \\
\hline & Constanta & 22.46 & 21.87 & 20.84 & 19.71 \\
\hline & Costinesti & 21.72 & 21.02 & 20.18 & 19.07 \\
\hline & Mangalia & 21.79 & 21.02 & 20.14 & 19.1 \\
\hline & \multirow[t]{2}{*}{ Vama Veche } & 21.94 & 21.28 & 20.55 & 19.62 \\
\hline & & \multirow{2}{*}{\multicolumn{4}{|c|}{$\begin{array}{cc}40 & 60 \\
\text { Distance from coastline }(\mathrm{km})\end{array}$}} \\
\hline & & & & & \\
\hline
\end{tabular}

Figure 6. Downtime period of the wind turbines (\%), considering the wind values located below the cut-in speed of: (a) GE Energy 2.5xl; (b) SWT-2.3-93; (c) Areva M5000-116.

On the other hand, this wind turbine will perform better close to Sulina $(16.29 \%)$, and also near Vama Veche $(17.17 \%)$ and Jurilovca $(17.59 \%)$. As for the marine sites, we may notice small differences between the two offshore sites, although they have the same cut-in limit $(4 \mathrm{~m} / \mathrm{s})$, but different operating hub heights. In the case of SWT-2.3-93, better performances are expected offshore because, in general, the downtime values do not exceed $20 \%$. For the Saint George location, the most appropriate site for a project development is close to the shore, in particular, at a distance of $40 \mathrm{~km}$, where a minimum value of $18.52 \%$ is expected. In general, the differences between the sites are relatively small $(<3 \%)$, and it is expected that a project operating close to Sulina at $20 \mathrm{~km}$ will have the same downtime window as the site located at $80 \mathrm{~km}$ offshore. A similar pattern is replicated by the Areva M5000-116 turbine, which indicates values in the range $18.86 \%$ (Jurilovca- $80 \mathrm{~km}$ ) and $22.96 \%$ (Navodari-20 km).

According to the previous results, two sites stand out in terms of the wind energy, namely Sulina (onshore) and the Saint George (40 km offshore). Taking this into account, in Figure 7, it is presented the distribution of the AEP index associated to the four main seasons: Winter (December-January-February), spring (March-April-May), summer (June-July-August), and autumn (September-October-November). For the GE Energy 2.5xl and SWT-2.3-93 systems, the expected electricity output is in the range (827-1934) MWh, with an estimated average output of 1380 MWh. Regarding the Areva M5000-116, better performances are expected during the winter time when a maximum of $4710 \mathrm{MWh}$ may occur, followed by Spring with 3003 MWh. This system generates, on average, around $3340 \mathrm{MWh}$ per season, while lower performances are expected during the summer. 


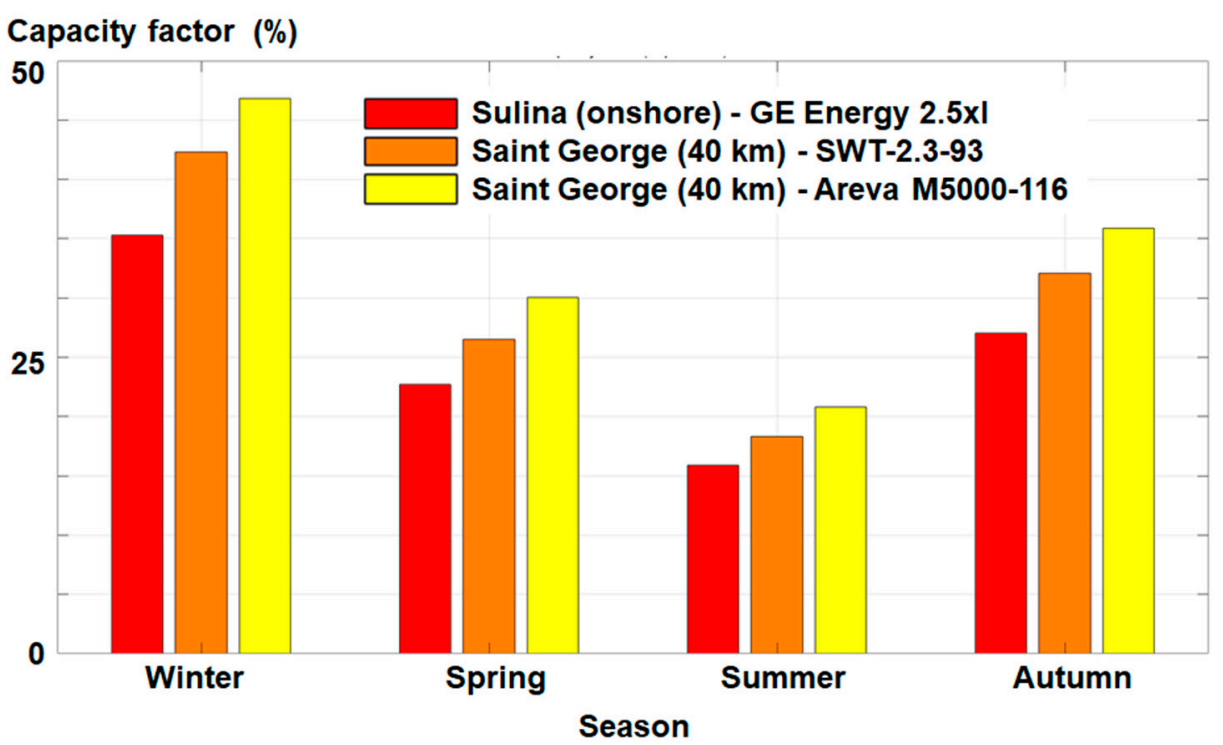

Figure 7. Seasonal distribution of the capacity factor (average values), corresponding to the sites Sulina onshore $(0 \mathrm{~km})$ and Saint George (40 $\mathrm{km}$ from the shore).

Figure 8 illustrates the variation of the AEP production, this time, considering the monthly fluctuations (in \%) associated to the annual output, where the results are grouped in two main intervals: October-March (six months) and April-September. The differences between the sites considered and the wind turbines are quite small, although it should be noted that the SWT-2.3-93 generator seems to present slightly higher variations. Nevertheless, during March and September, the other two turbines indicate higher variations.

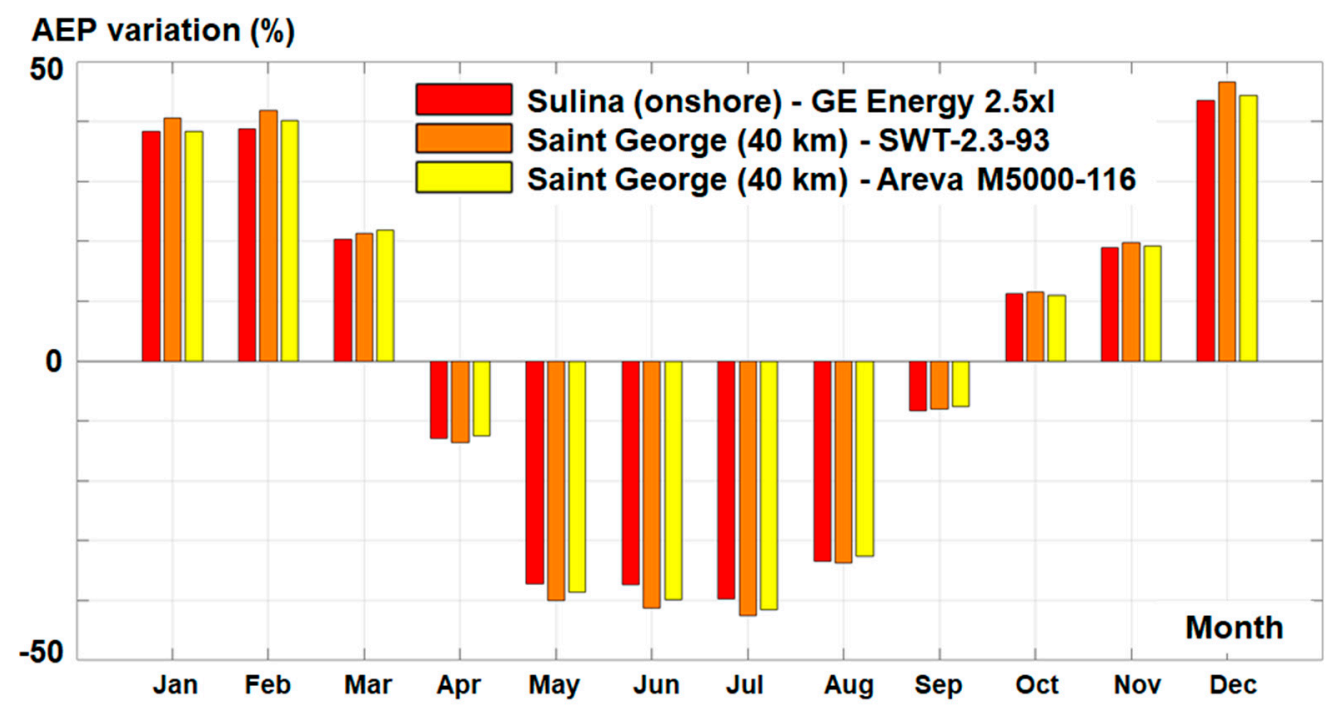

Figure 8. Monthly AEP variations considering as a reference the total time average values, indicated for Sulina onshore $(0 \mathrm{~km})$ and Saint George (40 km from the shore).

During the interval from December to February, the variations are in the range (38.32-46.53)\%, the percentage decreasing until $18.97 \%$ and $21.8 \%$ for March and November, respectively. From this group, during October we expect a minimum of $11 \%$ for the Areva M5000-116. As for the interval April-September, a maximum variation of $42.5 \%$ is expected for July, compared to only $7.6 \%$ indicated in September. 
The distribution of the capacity factor computed for all the sites considered is presented in Figure 9. By looking at these values, it can be noticed that the turbines selected do not exceed 30\%, while for the marine sites, SWT-2.3-93 has better performances.

\section{Capacity factor (\%)}

a) GE Energy 2.5xl (onshore)

b) SWT-2.3-93 (offshore)

\begin{tabular}{r|c|} 
Sulina & 25.18 \\
\cline { 2 - 2 } Saint George & 19.71 \\
\cline { 2 - 2 } Jurilovca & 22.46 \\
\cline { 2 - 2 } Vadul & 14.59 \\
\cline { 2 - 2 } Navodari & 11.54 \\
\cline { 2 - 2 } Constanta & 14.15 \\
\cline { 2 - 2 } Costinesti & 14.25 \\
\cline { 2 - 2 } Mangalia & 17.98 \\
\cline { 2 - 2 } Vama Veche & 23.73 \\
\cline { 2 - 2 } &
\end{tabular}

\begin{tabular}{|c|c|c|c|}
\hline 25.82 & 27.13 & 28.24 & 29.07 \\
\hline 27 & 29.73 & 29.48 & 29.08 \\
\hline 23.41 & 25.62 & 27.99 & 29.76 \\
\hline 22.85 & 24.45 & 26.64 & 28.58 \\
\hline 22.53 & 23.91 & 26 & 27.7 \\
\hline 23.25 & 24.61 & 26.57 & 28.65 \\
\hline 24.33 & 25.82 & 27.5 & 29.46 \\
\hline 28.65 & 25.89 & 27.46 & 29.44 \\
\hline 24.37 & 25.66 & 27.1 & 28.7 \\
\hline
\end{tabular}

\begin{tabular}{r|c|c|c|c|}
\multicolumn{1}{c}{} & \multicolumn{4}{c}{ c) Areva M5000-116 (offshore) } \\
\cline { 2 - 5 } Sulina & 29.18 & 30.58 & 31.78 & 32.66 \\
\cline { 2 - 5 } Saint George & 30.42 & 33.32 & 33.04 & 32.66 \\
\cline { 2 - 5 } Jurilovca & 26.52 & 28.9 & 31.46 & 33.34 \\
\cline { 2 - 5 } Vadul & 25.9 & 27.62 & 29.98 & 32.08 \\
\cline { 2 - 5 } Navodari & 25.52 & 27.04 & 29.3 & 31.14 \\
\cline { 2 - 5 } Constanta & 26.3 & 27.78 & 29.9 & 32.14 \\
\cline { 2 - 5 } Costinesti & 27.46 & 29.08 & 30.88 & 32.98 \\
\cline { 2 - 5 } Mangalia & 32.14 & 29.12 & 30.84 & 32.96 \\
\cline { 2 - 5 } & 27.48 & $\mathbf{2 8 . 8 6}$ & 30.44 & 32.16 \\
\cline { 2 - 5 } Vama Veche & $\mathbf{2 0}$ & $\mathbf{4 0}$ & $\mathbf{6 0}$ & $\mathbf{8 0}$ \\
& \multicolumn{4}{c}{ Distance from coastline (km) }
\end{tabular}

Figure 9. Capacity factor corresponding to: (a) GE Energy 2.5xl; (b) SWT-2.3-93; (c) Areva M5000-116.

The capacity factors computed for the onshore areas present values in the range (11.54-25.18)\%, with the Navodari site being considered the less attractive solution for a wind project. For the SWT-2.3-93 system, the Mangalia site $(20 \mathrm{~km})$ with $28.65 \%$ exceeds the values for all the sites located at this distance from the shore, as well as also for most of the marine sites located at $40 \mathrm{~km}$ and $60 \mathrm{~km}$. The sites located at $80 \mathrm{~km}$ offshore indicate for this system values around $29 \%$, except Navodari, where a value of $27.7 \%$ is indicated.

Areva M5000-116 is defined by the highest rated power, and also reports a higher capacity factor. For the $20 \mathrm{~km}$ limit, we expect a maximum of 32.14\% close to Mangalia, while for the $40 \mathrm{~km}$ limit, the sites located in the north (Sulina and Saint George) are more interesting. Going to $60 \mathrm{~km}$ offshore, we expect lower values for the sites located in the middle of this area (Vadul, Navodari and Constanta), while at the distance of $80 \mathrm{~km}$, the results are more homogenous, indicating a maximum value of $33.34 \%$ close to Jurilovca.

\section{Discussion}

At this moment, several aspects need to be discussed, and one of them is related to the accuracy of the ERA-Interim model to estimate the wind conditions over the land-water interface. By looking at the results presented in Figure 10, we can notice that there is a clear distinction between the two areas, with those corresponding to the offshore area indicating higher values. The wind speed interval between $4.4 \mathrm{~m} / \mathrm{s}$ and $5 \mathrm{~m} / \mathrm{s}$ seems to represent the transition between the land and water areas, with expected values close to $6.5 \mathrm{~m} / \mathrm{s}$ in the offshore regions. The reanalysis models seem to be suitable for the Black Sea environment, and this aspect is also reflected in one of the reports related to the ACCWA 
project (http://193.231.148.42/accwa/assets/pdf/raport_stiintific_ACCWA2017en.pdf), which is focused on climatological studies.

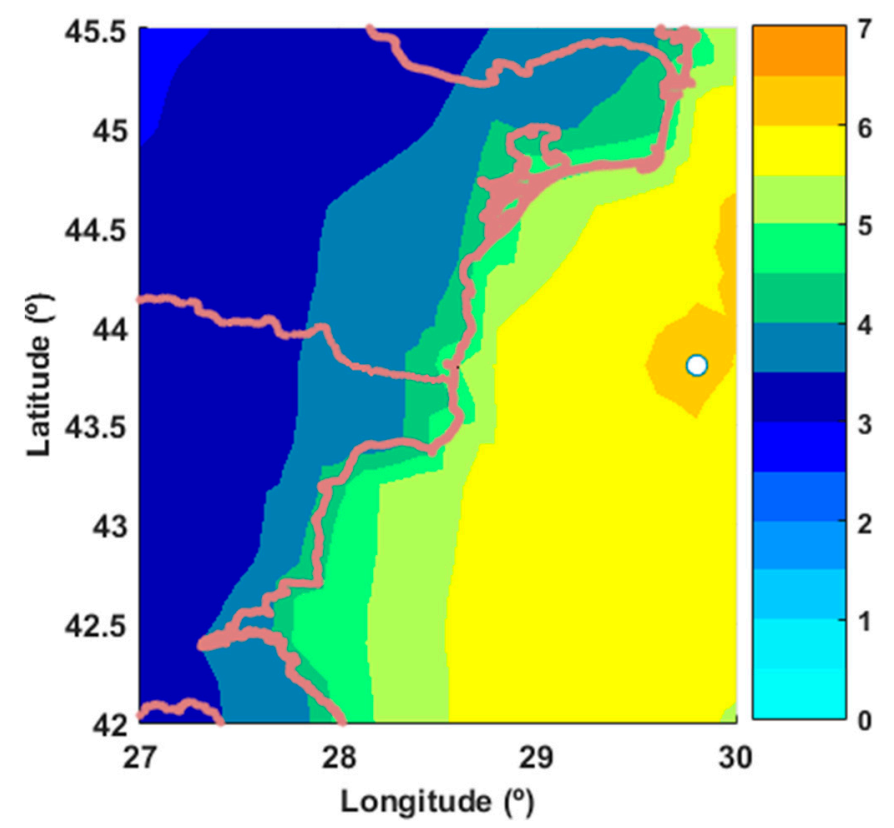

Figure 10. The spatial distribution of the average $U 10(\mathrm{~m} / \mathrm{s})$ over the Romanian coastal area. Results computed for the 20-year time interval from January 1998 to December 2017.

The smooth transition between land-nearshore-offshore is reflected much better in Figure 11, which is designed considering the entire dataset. From the analsysis of the onshore sites $(0 \mathrm{~km})$, we can notice that the profile changes as we go from north to south, with the group sites Vadul, Navodari, Constanta, and Costinesti being defined by a lower occurrence of the wind conditions that exceed $9 \mathrm{~m} / \mathrm{s}$. Since all the sites are located in the same area, the wind direction is similar for all of them follows the northeast-southwest axes. The $10 \%$ threshold seems to define the local wind roses, and smaller variations along this limit can also be noticed.

By looking at the previous results, it was noticed that significant variations occur between the references sites. A possible expalantion for this situation may result from a meteorological/climatological analysis that involves the monthly $(M V)$, seasonal $(S V)$, and annual $(A V)$ variations. The following Equations were used to assess the $M V, S V$, and $A V$ indexes [17]:

$$
M V=\frac{P_{M \max }-P_{M \min }}{P_{\text {average }}}, S V=\frac{P_{\text {Smax }}-P_{S \min }}{P_{\text {average }}}, A V=\frac{P_{\text {Amax }}-P_{\text {Amin }}}{P_{\text {average }}}
$$

where $P_{M \max }$ - the most energetic month; $P_{M \min }$ - the least energetic month; $P_{\text {average }}$-the average value of the entire dataset; similar for the season and annual variations.

According to the results presented in Figure 12, the seasonal and monthly variability indexes present similar values, while in the case of the annual index, lower values are noticed. From the onshore sites, a much higher seasonal variability is observed in the middle of this target area, more precisely, close to Navodari site, where a minimum value of 0.33 occurs. As we go offshore, the values gradually increase, reaching a maximum of $0.43-0.46$ in the vicinity of the sites located aproximately $80 \mathrm{~km}$ from shoreline. A lower value of 0.41 may be expected in the case of the seasonal index, especially in the case of the sites located in the southern part. By looking at the annual variability, we may notice that the sites located in the north (Sulina and Saint George) present lower fluctuations. Usually, these sites are indicated as more energetic, and this may represent a possible explanation. Maximum values of 0.15 and 0.16 are accounted by the sites Mangalia and Vama Veche, regardless of the reference point taken into account. 


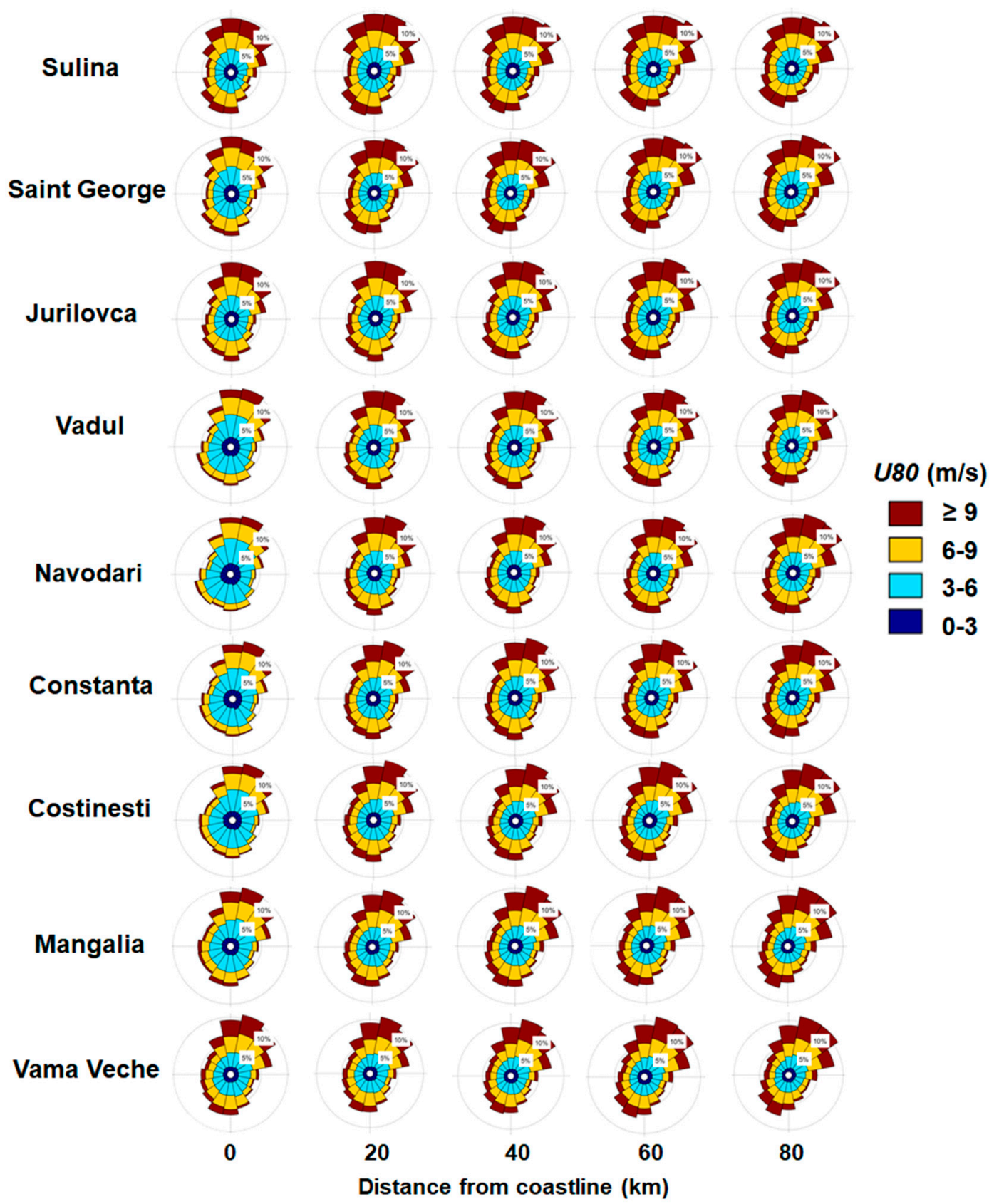

Figure 11. Wind roses (U80 parameter) reported for the full-time distribution, considering the ERA-Interim dataset processed for the 20-year time interval from January 1998 to December 2017.

An analysis of the parameter $U 80$ in the nine onshore sites (P1-P9) located along the Romanian shoreline is presented in Figure 13, considering the wind conditions at the Cogealac site, where a major wind farm operates (600 MW), as a reference. According to these results, computed only for the data located between the cut-in and cut-out values of the GE Energy 2.5xl system, the onshore sites selected indicate better wind conditions than the ones estimated at the Cogealac site $(5.8 \mathrm{~m} / \mathrm{s})$. 
a)

\begin{tabular}{|c|c|c|c|c|c|}
\multicolumn{7}{c}{} & \multicolumn{7}{c}{ Monthly variability } \\
\cline { 2 - 6 } Sulina & 0.39 & 0.40 & 0.42 & 0.44 & 0.45 \\
\cline { 2 - 6 } Saint George & 0.36 & 0.41 & 0.42 & 0.44 & 0.45 \\
\cline { 2 - 6 } Jurilovca & 0.36 & 0.38 & 0.40 & 0.41 & 0.43 \\
Vadul & 0.34 & 0.38 & 0.40 & 0.42 & 0.43 \\
\cline { 2 - 6 } Navodari & 0.33 & 0.39 & 0.40 & 0.42 & 0.43 \\
\hline Constanta & 0.35 & 0.40 & 0.41 & 0.43 & 0.44 \\
\hline Costinesti & 0.36 & 0.41 & 0.43 & 0.44 & 0.45 \\
\cline { 2 - 6 } Mangalia & 0.39 & 0.42 & 0.43 & 0.45 & 0.45 \\
\cline { 2 - 6 } Vama Veche & 0.42 & 0.43 & 0.44 & 0.45 & 0.46 \\
\cline { 2 - 6 } & 0 & 20 & $\mathbf{4 0}$ & $\mathbf{6 0}$ & $\mathbf{8 0}$ \\
& \multicolumn{7}{c}{ Distance from coastline (km) }
\end{tabular}

b) Seasonal variability

\begin{tabular}{|c|c|c|c|c|}
\hline 0.36 & 0.37 & 0.39 & 0.40 & 0.40 \\
\hline 0.34 & 0.38 & 0.39 & 0.40 & 0.40 \\
\hline 0.34 & 0.36 & 0.37 & 0.39 & 0.40 \\
\hline 0.32 & 0.36 & 0.37 & 0.39 & 0.40 \\
\hline 0.30 & 0.36 & 0.37 & 0.39 & 0.40 \\
\hline 0.33 & 0.37 & 0.38 & 0.39 & 0.40 \\
\hline 0.34 & 0.38 & 0.39 & 0.40 & 0.41 \\
\hline 0.36 & 0.38 & 0.39 & 0.40 & 0.41 \\
\hline 0.38 & 0.39 & 0.40 & 0.40 & 0.41 \\
\hline 0 & 20 & 40 & 60 & 80 \\
\hline \multicolumn{5}{|c|}{ Distance from coastline (km) } \\
\hline
\end{tabular}

c)

\begin{tabular}{|c|c|c|c|c|c|}
\multicolumn{7}{c}{} & \multicolumn{7}{c}{ Annual variability } \\
\cline { 2 - 6 } Sulina & 0.10 & 0.11 & 0.12 & 0.12 & 0.13 \\
\cline { 2 - 6 } Saint George & 0.11 & 0.12 & 0.12 & 0.13 & 0.13 \\
\cline { 2 - 6 } Jurilovca & 0.12 & 0.12 & 0.12 & 0.13 & 0.13 \\
\cline { 2 - 6 } Vadul & 0.12 & 0.13 & 0.13 & 0.13 & 0.13 \\
\cline { 2 - 6 } Navodari & 0.12 & 0.14 & 0.14 & 0.14 & 0.14 \\
\cline { 2 - 6 } Constanta & 0.13 & 0.14 & 0.14 & 0.14 & 0.14 \\
\cline { 2 - 6 } Costinesti & 0.14 & 0.15 & 0.15 & 0.15 & 0.15 \\
\cline { 2 - 6 } Mangalia & 0.15 & 0.15 & 0.15 & 0.15 & 0.15 \\
Vama Veche & 0.16 & 0.16 & 0.16 & 0.16 & 0.16 \\
\cline { 2 - 6 } & 0 & $\mathbf{2 0}$ & $\mathbf{4 0}$ & $\mathbf{6 0}$ & $\mathbf{8 0}$
\end{tabular}

Figure 12. The variability of $U 10$ from the ERA-Interim database computed in each site: (a) Monthly variability; (b) seasonal variability; (c) annual variability.

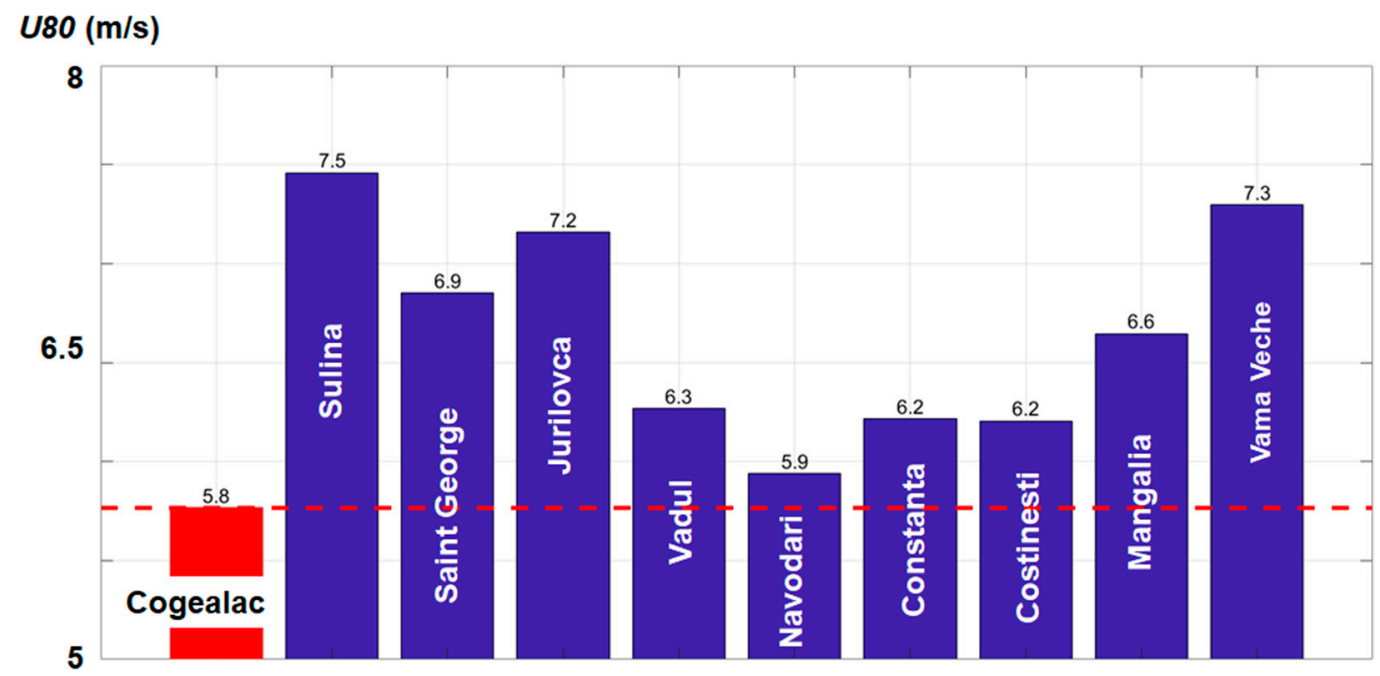

Figure 13. Direct comparison of the $U 80$ parameter (average values) between the conditions corresponding to Fantanele-Cogealac farm site and the nine onshore sites defined along the Romanian coastal environment. Results available for the 20-year time interval from January 1998 to December 2017, considering only the data between the cut-in and cut-out values of the GE Energy 2.5xl system.

In the top three sites, we can notice Sulina $(7.5 \mathrm{~m} / \mathrm{s})$, Vama Veche $(7.3 \mathrm{~m} / \mathrm{s})$, and Jurilovca $(7.2 \mathrm{~m} / \mathrm{s})$, compared to $5.9 \mathrm{~m} / \mathrm{s}$ corresponding to Navodari or $6.2 \mathrm{~m} / \mathrm{s}$ indicated for the sites Constanta and Costinesti.

Since, at this moment, there are no offshore wind farms operating in the Romanian nearshore, another objective will be to establish what type of project would be suitable for this environment. By comparing the average wind speed (U80) estimated for some European marine wind projects with the resources reported near the site Saint George ( $20 \mathrm{~km}$ offshore), it is possible to identify the top nine projects presenting relatively similar values. The initial screening of the results was made by considering a total number of 171 projects (operational or still under construction) developed in 
the coastal waters of France, Netherland, and Denmark [43]. Figure 14a illustrates these differences, from which we notice that the Saint George site presents similar values with the ones from ENOVA (Germany) and much higher than the sites Fecamp (France) and Irene (Netherland).

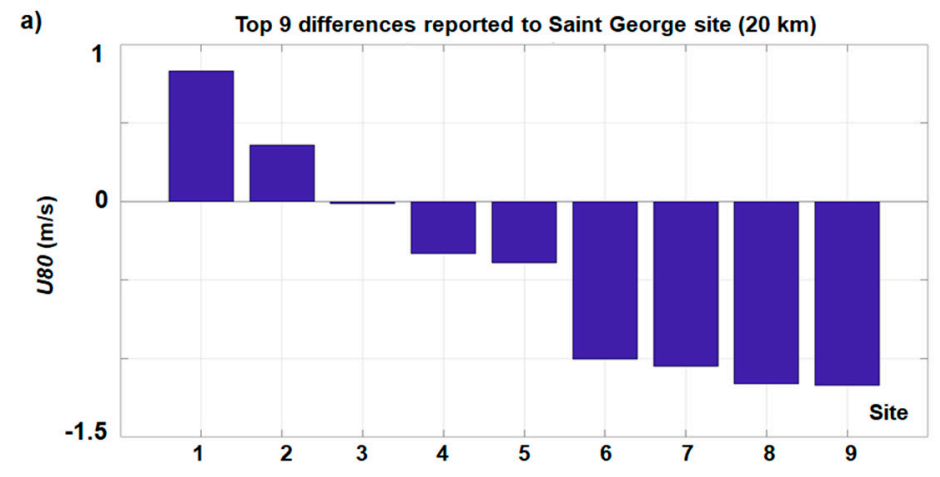

Site

A Saint George (20 km)

1. Fecamp* (FR)

2. Irene (NL)

3. ENOVA (DE)

4. Levenmouth (UK)

5. ForthWind ${ }^{*}(U K)$

$\square$ 6. Gulf Lion* (FR)

7. Teeside (UK)

8. Westermeerwind (NL)

$\square$ 9. EolMed $^{\star}(\mathrm{FR})$ (b)

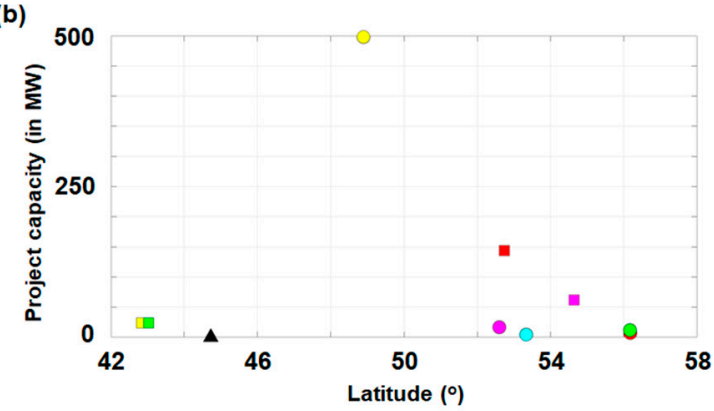

(c)

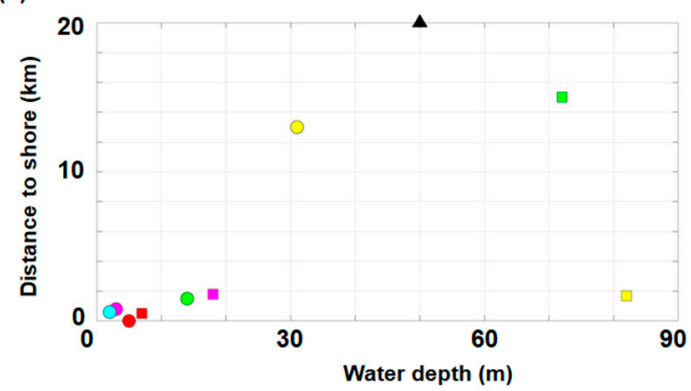

Figure 14. Direct comparison between the wind conditions reported close to the Saint George area (20 km offshore) and some European wind projects. The projects under construction are marked with the asterisk symbol $\left({ }^{*}\right)$. Results indicated for: (a) U80 differences considering Saint George as a reference; (b) associated project capacities and latitudes; (c) associated distance to shore and water depth. Results available for the 20-year time interval from January 1998 to December 2017.

For the remaining sites, Saint George shows smaller values, with expected differences of $0.33 \mathrm{~m} / \mathrm{s}$ and $1.17 \mathrm{~m} / \mathrm{s}$ corresponding to the projects Levenmouth (United Kingdom) and EolMed (France). More details about the sites selected are provided in Figure $14 b$, considering the project capacity and the latitudes of the sites. In terms of latitude, only the projects EolMed and Gulf Lion are located at a similar latitude as Saint George, while the other sites are located between $52.6^{\circ}$ and $56.2^{\circ} \mathrm{N}$. The project capacity may be more relevant, from which we notice that the values estimated are quite low, being associated with pilot projects or testing sites located in the range 4.5-24.6 MW. More consistent projects are Teeside with 62.1 MW and Westermeerwind with $144 \mathrm{MW}$, and also the case of Parc Fecamp project that indicates a maximum of $498 \mathrm{MW}$ and which seems to be characterized by lower wind resources than Saint George.

Regarding the water depth and the distance from the shore (Figure 14c), we notice that the Saint George site stands out with higher values, being exceeded only by the projects ForthWind and Gulf Lion that exceed, however, a water depth of $72 \mathrm{~m}$. Most of the projects are grouped in the water depth ranging from $2 \mathrm{~m}$ to $18 \mathrm{~m}$, while regarding the distance from the shore, we can mention the interval 0-1.8 km. The project Gulf Lion is located at distance of $13 \mathrm{~km}$, while the site EolMed is at $15 \mathrm{~km}$.

\section{Conclusions}

In the present work, an assessment of the offshore wind resources characterizing the Romanian coastal sector was carried out. The performances of some state-of-the-art wind generators were also taken into account. By processing the ERA-Interim wind data covering the 20-year time interval from January 1998 to December 2017, it was possible to identify the most promising sites in terms of the 
wind potential. Furthermore, the evolution of some relevant wind parameters was quantified in a concise way. Since, at this moment, the in-situ measurements are quite limited in this area, the use of the reanalysis data seems to represent one of the best solutions to provide a more complete picture of the local wind characteristics. Another limitation can be considered the fact that only four data per day are available, and thus, it is impossible to highlight some events, such as the diurnal/nocturnal fluctuations of the wind.

Regarding the original research questions, the outcomes of the present work indicate that:

(a) The offshore wind resources appear to be more consistent than onshore, with expected maximum variations of the wind energy of about $55.85 \%$ between the shoreline and the $20 \mathrm{~km}$ interval;

(b) More important wind resources are noticed in the northern region close to the Danube Delta. On the other hand, more significant variations are expected in the central part of the target area, especially in the case of the onshore sites, where a maximum decrease of $139.2 \%$ was noticed (close to Navodari). As we go offshore, the wind conditions are more homogenous, with an expected maximum fluctuation of $10 \%$ at $80 \mathrm{~km}$ offshore;

(c) With regards the onshore sites, the best site to develop a wind project is Sulina $(0 \mathrm{~km})$, while for the offshore sites, the area in the vicinity of Saint George seems to present a good potential. The Mangalia site, located at $20 \mathrm{~km}$ from the shore, is also included in this category;

(d) From the comparison with some other European sites, it seems that, at this moment, for the Romanian area, it will be more suitable to develop a pilot project or testing areas, involving only a limited number of turbines.

Besides these aspects, another issue seems to be related to the high water depth corresponding to the Romanian sites. This issue can be easily overcome taking into account that the new generation of offshore wind turbines, also including the floating platforms, is designed especially for such environments. More than this, since the Black Sea is an enclosed basin, the extreme wave conditions are less severe than in the coastal areas facing the ocean environment, and for this reason, the survivability of the wind turbines will be less affected. Overall, the present work indicates that the Romanian coastal environment could successfully support an offshore wind farm using the expertise accumulated by the local onshore industry, where major projects are already operating.

Author Contributions: F.O. performed the literature review, processed the wind dataset, carried out the statistical analysis and written the manuscript. L.R. guide this research, written parts of the manuscript and handles the review process. All the authors approved the final manuscript.

Funding: This work was supported by a grant of Ministery of Research and Innovation, CNCS-UEFISCDI, project number PN-III-P1-1.1-PD-2016-0235, within PNCDI III.

Acknowledgments: ERA-Interim data used in this study have been obtained from the ECMWF data server.

Conflicts of Interest: The authors declare no conflict of interest.

\section{Nomenclature}

$\begin{array}{ll}\text { AEP } & \text { Annual Energy Production } \\ \text { ECMWF } & \text { European Centre for Medium-Range Weather Forecasts } \\ E E Z & \text { Exclusive Economic Zones } \\ \text { EU } & \text { European Union } \\ f(u) & \text { Weibull probability density function } \\ \text { LCOE } & \text { levelized cost of electricity } \\ P(u) & \text { power curve of a turbine } \\ T & \text { average hours per year }(8760 \mathrm{~h} / \text { year }) \\ U 10 & \text { wind speed reported at } 10 \mathrm{~m} \text { above sea level } \\ U 80 & \text { wind speed associated to } 80 \mathrm{~m} \text { height above sea level } \\ z_{0} & \text { roughness of the sea surface } \\ z_{10} ; z_{80} & \text { reference heights }\end{array}$




\section{References}

1. Arrambide, I.; Zubia, I.; Madariaga, A. Critical review of offshore wind turbine energy production and site potential assessment. Electr. Power Syst. Res. 2019, 167, 39-47. [CrossRef]

2. Bento, N.; Fontes, M. Emergence of floating offshore wind energy: Technology and industry. Renew. Sustain. Energy Rev. 2019, 99, 66-82. [CrossRef]

3. Thomsen, J.B.; Ferri, F.; Kofoed, J.P. Validation of a Tool for the Initial Dynamic Design of Mooring Systems for Large Floating Wave Energy Converters. J. Mar. Sci. Eng. 2017, 5, 45. [CrossRef]

4. Liu, J.; Thomas, E.; Manuel, L.; Griffith, D.T.; Ruehl, K.M.; Barone, M. Integrated System Design for a Large Wind Turbine Supported on a Moored Semi-Submersible Platform. J. Mar. Sci. Eng. 2018, 6, 9. [CrossRef]

5. Analyst, R.H.B. Environment Offshore Wind Cheaper Than New Nuclear. Available online: https://www. bbc.com/news/business-41220948 (accessed on 28 February 2019).

6. The European Offshore Wind Industry—Key Trends and Statistics 2017. Available online: https://windeurope. org/about-wind/statistics/offshore/european-offshore-wind-industry-key-trends-statistics-2017/ (accessed on 2 April 2018).

7. Study: Levelized Cost of Electricity-Renewable Energy Technologies-Fraunhofer ISE. Available online: https://www.ise.fraunhofer.de/en/publications/studies/cost-of-electricity.html (accessed on 22 February 2019).

8. Rusu, E.; Onea, F. Joint Evaluation of the Wave and Offshore Wind Energy Resources in the Developing Countries. Energies 2017, 10, 1866. [CrossRef]

9. Onea, F.; Ciortan, S.; Rusu, E. Assessment of the potential for developing combined wind-wave projects in the European nearshore. Energy Environ. 2017, 28, 580-597. [CrossRef]

10. Onea, F.; Rusu, E. Sustainability of the Reanalysis Databases in Predicting the Wind and Wave Power along the European Coasts. Sustainability 2018, 10, 193. [CrossRef]

11. Onea, F.; Deleanu, L.; Rusu, L.; Georgescu, C. Evaluation of the wind energy potential along the Mediterranean Sea coasts. Energy Explor. Exploit. 2016, 34, 766-792. [CrossRef]

12. Balog, I.; Ruti, P.M.; Tobin, I.; Armenio, V.; Vautard, R. A numerical approach for planning offshore wind farms from regional to local scales over the Mediterranean. Renew. Energy 2016, 85, 395-405. [CrossRef]

13. Satir, M.; Murphy, F.; McDonnell, K. Feasibility study of an offshore wind farm in the Aegean Sea, Turkey. Renew. Sustain. Energy Rev. 2018, 81, 2552-2562. [CrossRef]

14. Dragomir, G.; Șerban, A.; Năstase, G.; Brezeanu, A.I. Wind energy in Romania: A review from 2009 to 2016. Renew. Sustain. Energy Rev. 2016, 64, 129-143. [CrossRef]

15. Ilkiliç, C.; Aydin, H. Wind power potential and usage in the coastal regions of Turkey. Renew. Sustain. Energy Rev. 2015, 44, 78-86. [CrossRef]

16. Kaplan, Y.A. Overview of wind energy in the world and assessment of current wind energy policies in Turkey. Renew. Sustain. Energy Rev. 2015, 43, 562-568. [CrossRef]

17. Rusu, L.; Raileanu, A.B.; Onea, F. A Comparative Analysis of the Wind and Wave Climate in the Black Sea Along the Shipping Routes. Water 2018, 10, 924. [CrossRef]

18. Ganea, D.; Mereuta, E.; Rusu, L. Estimation of the Near Future Wind Power Potential in the Black Sea. Energies 2018, 11, 3198. [CrossRef]

19. Rusu, E. A 30-year projection of the future wind energy resources in the coastal environment of the Black Sea. Renew. Energy 2019, 139, 228-234. [CrossRef]

20. Koletsis, I.; Kotroni, V.; Lagouvardos, K.; Soukissian, T. Assessment of offshore wind speed and power potential over the Mediterranean and the Black Seas under future climate changes. Renew. Sustain. Energy Rev. 2016, 60, 234-245. [CrossRef]

21. Aydogan, B. Offshore wind power atlas of the Black Sea Region. J. Renew. Sustain. Energy 2017, 9, 013305. [CrossRef]

22. Archer, C.L.; Jacobson, M.Z. Spatial and temporal distributions of US winds and wind power at $80 \mathrm{~m}$ derived from measurements. J. Geophys. Res.-Atmos. 2003, 108, 4289. [CrossRef]

23. Onea, F.; Rusu, E. Efficiency assessments for some state of the art wind turbines in the coastal environments of the Black and the Caspian seas. Energy Explor. Exploit. 2016, 34, 217-234. [CrossRef]

24. Onea, F.; Rusu, L. Evaluation of Some State-Of-The-Art Wind Technologies in the Nearshore of the Black Sea. Energies 2018, 11, 2452. [CrossRef] 
25. Raileanu, A.; Onea, F.; Rusu, E. Assessment of the Wind Energy Potential in the Coastal Environment of Two Enclosed Seas. In Proceedings of the OCEANS 2015, Genova, Italy, 18-21 May 2015; IEEE: New York, NY, USA, 2015; ISBN 978-1-4799-8737-5.

26. Davy, R.; Gnatiuk, N.; Pettersson, L.; Bobylev, L. Climate change impacts on wind energy potential in the European domain with a focus on the Black Sea. Renew. Sustain. Energy Rev. 2018, 81, 1652-1659. [CrossRef]

27. Rusu, L. The wave and wind power potential in the western Black Sea. Renew. Energy 2019, 139, 1146-1158. [CrossRef]

28. Onea, F.; Rusu, E. Wind energy assessments along the Black Sea basin. Meteorol. Appl. 2014, 21, 316-329. [CrossRef]

29. Văidianu, N.; Ristea, M. Marine spatial planning in Romania: State of the art and evidence from stakeholders. Ocean Coast. Manag. 2018, 166, 52-61. [CrossRef]

30. Dee, D. ERA-Interim. Available online: https:/www.ecmwf.int/en/forecasts/datasets/archive-datasets/ reanalysis-datasets/era-interim (accessed on 15 May 2018).

31. Dee, D.P.; Uppala, S.M.; Simmons, A.J.; Berrisford, P.; Poli, P.; Kobayashi, S.; Andrae, U.; Balmaseda, M.A.; Balsamo, G.; Bauer, P.; et al. The ERA-Interim reanalysis: Configuration and performance of the data assimilation system. Q. J. R. Meteorol. Soc. 2011, 137, 553-597. [CrossRef]

32. Onea, F.; Rusu, E. An Evaluation of the Wind Energy in the North-West of the Black Sea. Int. J. Green Energy 2014, 11, 465-487. [CrossRef]

33. Onea, F.; Raileanu, A.; Rusu, E. Evaluation of the Wind Energy Potential in the Coastal Environment of Two Enclosed Seas. Adv. Meteorol. 2015, 2015, 808617. [CrossRef]

34. Archer, C.L.; Jacobson, M.Z. Evaluation of global wind power. J. Geophys. Res. Atmos. 2005, 110. [CrossRef]

35. Onea, F.; Rusu, E. The expected efficiency and coastal impact of a hybrid energy farm operating in the Portuguese nearshore. Energy 2016, 97, 411-423. [CrossRef]

36. Kubik, M.L.; Coker, P.J.; Hunt, C. Using meteorological wind data to estimate turbine generation output: A sensitivity analysis. In Proceedings of the World Renewable Energy Congress, Linköping, Sweden, 8-13 May 2011; Linkoping University: Linköping, Sweden, 2011; pp. 4074-4081.

37. GE Energy 2.5xl-Manufacturers and Turbines-Online Access-The Wind Power. Available online: https://www.thewindpower.net/turbine_en_59_ge-energy_2.5xl.php (accessed on 10 March 2019).

38. Siemens Wind Turbine SWT-2.3-93. Available online: http://pdf.archiexpo.com/pdf/siemens/swt-23-93/88089134477-_6.html (accessed on 10 March 2019).

39. Siemens SWT-2.3-93-Manufacturers and Turbines-Online Access-The Wind Power. Available online: https://www.thewindpower.net/turbine_en_22_siemens_swt-2.3-93.php (accessed on 10 March 2019).

40. Areva M5000-116-Manufacturers and Turbines-Online Access-The Wind Power. Available online: https://www.thewindpower.net/turbine_en_326_areva_m5000-116.php (accessed on 10 March 2019).

41. Salvacao, N.; Guedes Soares, C. Wind resource assessment offshore the Atlantic Iberian coast with the WRF model. Energy 2018, 145, 276-287. [CrossRef]

42. Al-Nassar, W.K.; Neelamani, S.; Al-Salem, K.A.; Al-Dashti, H.A. Feasibility of offshore wind energy as an alternative source for the state of Kuwait. Energy 2019, 169, 783-796. [CrossRef]

43. 4C Offshore Overview-4C Offshore. Available online: https://www.4coffshore.com/ (accessed on 12 March 2019).

(C) 2019 by the authors. Licensee MDPI, Basel, Switzerland. This article is an open access article distributed under the terms and conditions of the Creative Commons Attribution (CC BY) license (http://creativecommons.org/licenses/by/4.0/). 